\title{
SIGLEC9 wt Allele
}

National Cancer Institute

\section{Source}

National Cancer Institute. SIGLEC9 wt Allele. NCI Thesaurus. Code C123870.

Human SIGLEC9 wild-type allele is located in the vicinity of 19q13.41 and is approximately $14 \mathrm{~kb}$ in length. This allele, which encodes sialic acid-binding Ig-like lectin 9 protein, plays a role in both cell adhesion and sialic acid binding. 